Omni-Akuatika, 14 (1): 77-86, 2018
ISSN: 1858-3873 print / 2476-9347 online
Research Article
journal homepage: http://ojs.omniakuatika.net

\title{
Dominant Water Quality Variables Affecting Plankton Abundance in Traditional Brackish Water Ponds of Tiger Shrimp (Penaeus monodon Fabr.) in Pasuruan Regency, East Java Province
}

\author{
Erfan Andi Hendrajat ${ }^{{ }^{\star}}$, Andi Sahrijanna ${ }^{1}$ \\ ${ }^{1}$ Research Institute for Coastal Aquaculture, Maros, South Sulawesi, Sulawesi Selatan \\ ${ }^{*}$ Correspondensi: Erfanhendrajat67@gmail.com
}

Received 14 September 2017; Accepted 13 May 2018; Available online 31 May 2018

\begin{abstract}
Applying traditional brackish water pond aquaculture of tiger shrimp (Penaeus monodon), plankton is one of water microorganisms that plays an important role as natural food and stability indicator of water or aquatic environment in which life and growth of aquatic organisms depend on water quality variables, both physical and chemical properties. The aim research was to find out the effects of dominant water variables on plankton abundance in brackish-water pond. The research was conducted in traditional brackish water ponds of tiger shrimp in Pasuruan Regency, East Java Province. The research was conducted through direct measurements in the field and also collection of plankton and water samples. Metod experimental design. Better change to analysis used in this study was regression model analysis was based on the smallest square method. Dependent variables was plankton abundance and independent variables were the water quality variables such as temperature, dissolved oxygen, salinity, $\mathrm{pH}$, total suspended solid (TSS), nitrite, nitrate, ammonia, phosphate, iron $(\mathrm{Fe})$, and total organic matter (TOM). The result showed that range of plankton abundance was 20.06,360 individuals/L with average $401.3 \pm 2,886.43$ individuals/L. There was a significant relationship between plankton abundance and TSS which negatively affected plankton abundance. Based on index values of average dominance, variety, and uniformity, the brackish water pond water or aquatic area in this study was categorized as moderately stable, where plankton genera were well distributed and there was no genus dominating other genus.
\end{abstract}

Keywords: affective, water quality, plankton, brackish water ponds, Pasuruan Regency

\section{Introduction}

The business of brackish water pond aquaculture is one ways for utilizing of the coastal region. This aquaculture practice is expected to give a big contribution to local income, prosperity increase of the aquaculture farmers and also National foreign exchange. Pasuruan Regency, East Java Province has coastal areas for the development of aquaculture including to fisheries industrialization area with the tiger shrimp as the superior commodities. This district is eligible to be developed into a regional aquaculture (minapolitan) among others having land and water resources which is suitable for the developing of competitive commodity aquaculture and the adequate infrastructure to support the system development as systems as human resources who are willing and potentially for the development of independent aquaculture (Anonim, 2010a). Recently, the business of brackish-water pond aquaculture in Pasuruan Regency covers the area of about $3,966.9$ ha and production achieved in 2008 amounted to $3,383.98$ tons (Anonim, 2008), with tiger shrimp ( $P$. monodon) as main commodity, and using traditional aquaculture technique. The characteristic pond in this area are old pond, variety of sizes, relatively tall of dykes, one inlet and outlet systems, water source from sea and river, and water changing largely depends on different of high-low tide.

In the traditional brackish water pond, plankton is one micro-organisms that become the main natural food source for the cultured shrimps, so an increase in pond aquaculture productivity largely depends on the availability of planktonin the pond. Besides that, plankton are also the main component in determining the level of stability and fertility as well as potential estimator of water or aquatic area. According to Barnes \& Mann (1991), plankton production level in water or aquatic area can be used to 
predict the production potential of shrimps and fish. When plankton population in water or aquatic area is blooming (over saturated), it is an indication of biological pollution.

The plankton consist of microscopic plants (phytoplankton) and animals (zooplankton). On the smaller end of the spectrum exist bacteria (bacterioplankton) and viruses (virioplankton). Plankton also consist of the early life stages of much larger organisms, such as fish eggs and larvae (ichthyoplankton), which are both part of and dependant on the plankton itself. Photosynthesis by the phytoplankton accounts for up to half of global primary production. They also provide the primary food source for the zooplankton, and together form the base of the oceanic food chain. Larger and larger zooplankton, fish, and mammals depend on these plankton for their survival. Tying it all together, the bacterioplankton play an important role in the recycling and remineralization of materials and energy within the food chain (Anonym, 2010).

Failures of shrimp pond aquaculture activity in this decade because of several factors such as decreasing of environment factors of pond aquaculture water or aquatic area due to land function changing, outbreak of some diseases due to brackish water pond remediation at the time of preparing and changing the pond water during its poor management which give bad impacts and decrease the production of brackish water pond aquaculture. The production still has a big opportunity to be increased through an improvement in water quality through plankton management complemented with an improvement in the construction and network of brackish water pond irrigation. The management of plankton (phytoplankton and zooplankton) as natural food for shrimps through fertilization can significantly contribute to the success of brackish water pond aquaculture business. Phytoplankton besides as a nutrient source for shrimps also has an important role in improving water quality and maintaining environment balance and can remove toxic compounds, so it can enhance growth and minimize the rate of mortality of shrimps being cultured (Pirzan \& Pong Masak,
2007). Besides that, maintaining and keeping plankton abundance to the optimum level in brackish water pond through balanced fertilization will prevent the environment from degradation and can ensure dissolved oxygen to stay appropriately available for the shrimps being cultured. According to Boyd (1990), the ecosystem of water or aquatic area having low organic variety is not stable and fragile towards influences from outside compared to the ecosystem having high organic variety. A stable and prime brackish water pond is marked with high plankton variety, large numbers of individuals of each plankton species, well distributed plankton species, and suitable water quality in the brackish water pond environment is within a range which is suitable with the growth of shrimps being cultured. The aim research was to find out the effects of dominant water variables on plankton abundance in brackish-water ponds in Pasuruan Regency, East Java Province.

\section{Materials and Methods}

The research was conducted in brackish water pond areas in Pasuruan Regency, East Java Province. Seventy two observation stations were set by using Global Positioning System (GPS) and the station distribution is shown in Figure 1. In every station, plankton and water samples were taken from traditional brackish water ponds of tiger shrimps ( $P$. monodon) being managed.

The water quality variables measured were consisted of physical and chemical variables which were considered to affect plankton abundance as shown in Table 1. Water samples were taken from locations considered to represent the brackish water pond, water or aquatic area environmental condition and the analysis method following method from Haryadi et al. (1992) and APHA (2005). Water quality variables were determined through direct measurement in the field (Dissolved oxygen, Salinity, and $\mathrm{pH}$ ) and were analyzed in laboratory Research and Development Institute for Coastal Aquaculture, Maros (TSS, $\mathrm{NO}_{2}, \mathrm{NO}_{3}, \mathrm{NH}_{3}, \mathrm{PO}_{4}, \mathrm{Fe}$ and Total organic matter). 
Table 1. Variables of water quality were collected and analyzed in brackish water pond area of Pasuruan Regency, East Java Province

\begin{tabular}{|c|c|c|}
\hline Variables & Tool/Method & $\begin{array}{c}\text { Analyses } \\
\text { Laboratory/Field }\end{array}$ \\
\hline $\begin{array}{l}\text { Physical } \\
\text { Temperature }\left({ }^{\circ} \mathrm{C}\right)\end{array}$ & DO-meter & Field \\
\hline $\begin{array}{l}\text { Chemical } \\
\text { Dissolved oxygen (mg/L) } \\
\text { Salinity }(\mathrm{ppt}) \\
\mathrm{pH} \\
\mathrm{TSS}(\mathrm{mg} / \mathrm{L}) \\
\mathrm{NO}_{2}(\mathrm{mg} / \mathrm{L}) \\
\mathrm{NO}_{3}(\mathrm{mg} / \mathrm{L}) \\
\mathrm{NH}_{3}(\mathrm{mg} / \mathrm{L}) \\
\mathrm{PO}_{4}(\mathrm{mg} / \mathrm{L}) \\
\mathrm{Fe}(\mathrm{mg} / \mathrm{L}) \\
\text { Total organic matter }(\mathrm{mg} / \mathrm{L})\end{array}$ & $\begin{array}{l}\text { DO-meter } \\
\text { Refractometer } \\
\text { pH-meter } \\
\text { Gravimetric } \\
\text { Sample bottle, spectrophotometer } \\
\text { Sample bottle, cadmium reduction } \\
\text { Sample bottle, phenate } \\
\text { Sample bottle, askorbic acid } \\
\text { Sample bottle, phenanthroline } \\
\text { Titrimetric }\end{array}$ & $\begin{array}{l}\text { Field } \\
\text { Field } \\
\text { Field } \\
\text { Laboratory } \\
\text { Laboratory } \\
\text { Laboratory } \\
\text { Laboratory } \\
\text { Laboratory } \\
\text { Laboratory } \\
\text { Laboratory }\end{array}$ \\
\hline $\begin{array}{l}\text { Biological } \\
\text { Plankton (phytoplankton } \\
\text { and zooplankton) }\end{array}$ & $\begin{array}{l}\text { Plankton net size } 60 \mu \mathrm{m} \text {, sample } \\
\text { bottles, preservative, microscope }\end{array}$ & Laboratory \\
\hline
\end{tabular}

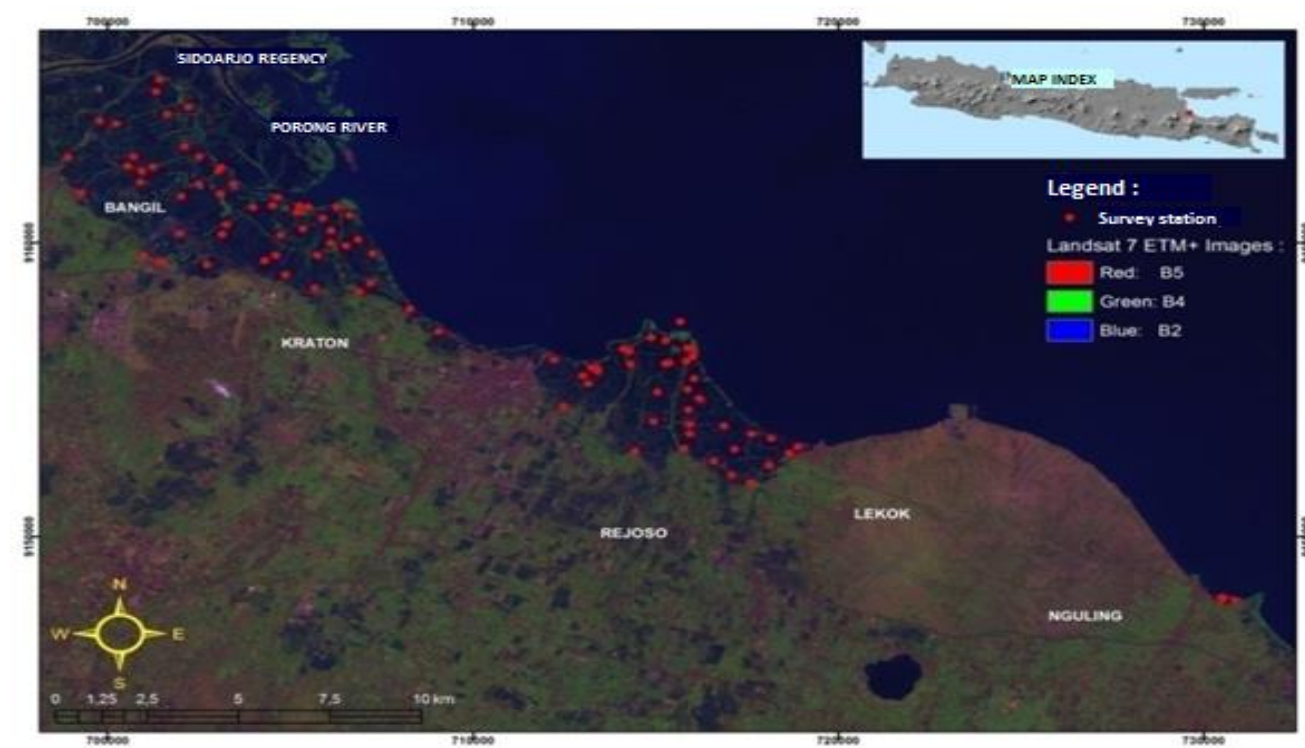

Figure 1. Distribution of sampling sites in brackish water pond area of Pasuruan Regency, East Java Province.

Plankton were collected by filtering $50 \mathrm{~L}$ of brackish water pond water to become $30 \mathrm{~mL}$ by using plankton net number 25 mesh size 60 $\mu$ with diameter $25 \mathrm{~cm}$ and then they were preserved using lugol solution $1 \%$. Plankton were analyzed by using microscopes in Laboratory Research and Development Institute for Coastal Aquaculture, Maros and following the methods from Newel and Newel (1977), Yamaji (1976) and Botes (2003). Determination of plankton abundance was conducted using Sedgwick Rafter Counting Cell (APHA, 2005). To find out the water or aquatic area stability, plankton biological index quantitative analysis was conducted, including the calculations of variety, uniformity, and dominance index from Shannon-Wiener (Odum, 1971; Basmi, 2000) using formula as follows:

$$
\begin{gathered}
H^{\prime}=-\sum P i \ln P i \\
P i=\frac{n i}{N}
\end{gathered}
$$

Where:

$\mathrm{H}^{\prime}=$ Type variety index

$n i=$ Number of of ${ }^{\text {th }}$ individuals

$\mathrm{N}=$ Total number of individuals

$\mathrm{Pi}=n \mathrm{i} / \mathrm{N}=$ Proportion of $\mathrm{i}^{\text {th }}$ genus 


$$
E=\frac{H^{\prime}}{H^{\prime} \max }
$$

Where:

$\mathrm{E} \quad=$ Type uniformity index

$\mathrm{H}^{\prime} \quad$ = Type variety index

$H^{\prime} \max =$ Maximum variety index

$$
\mathrm{D}=(\mathrm{Pi})^{2}
$$

Where:

$$
\begin{array}{ll}
\mathrm{D} & =\text { Dominance index } \\
\mathrm{Ni} & =\text { Number of } \mathrm{i}^{\text {th }} \text { individuals } \\
\mathrm{N} & =\text { Total number of individuals } \\
\mathrm{Pi} & =\text { ni/N }=\text { Proportion of species } \mathrm{i}^{\text {th }}
\end{array}
$$

Descriptive statistics was used to describe general description (minimum, maximum, average, and standard deviation) of abundance and number of genera, biological index (variety, uniformity, and dominance) of plankton and water or aquatic area environmental condition. Dependent variable in this research was plankton abundance, while independent variables were the water quality variables. The calculation result of $R$ (correlation coefficient) value between plankton abundance and water quality variables would indicate the relationship among variables. To calculate how much the water quality variables affected plankton abundance, the value of $R^{2}$ (determination coefficient) was used. A test of the correctness or appropriateness of the regression model used was carried out using test of linearity relationship between water quality variables and plankton abundance. The statistics significance level was set at $p<0.05$. The data were analyzed using Statistical Product Service Solution (SPSS) 15.0 (SPSS, 2006) software.

\section{Results and Discussion}

The physical variables such as temperature and chemical variables such as dissolved oxygen, salinity, $\mathrm{pH}$, TSS, $\mathrm{NO}_{2}, \mathrm{NO}_{3}$, $\mathrm{NH} 3, \mathrm{PO}_{4}, \mathrm{Fe}$ and total organic matter are the most important parameters for the management of the pond water. The best growth performance of shrimp and fish can be achieved only in optimum condition of these environmental factors. Water quality variables in brackish water pond area of Pasuruan Regency shown in Table 2.

Water temperature in the research location ranged between 27.17-34.73 ${ }^{\circ} \mathrm{C}$ averaging $31.59 \pm 1.5099{ }^{\circ} \mathrm{C}$. The optimum temperature range for growth phytoplankton is 20-30 ${ }^{\circ} \mathrm{C}$ (Effendi, 2003). Dissolved oxygen measurement results ranged between 1.33$11.97 \mathrm{mg} / \mathrm{L}$ averaging 7.69 $\pm 2.6518 \mathrm{mg} / \mathrm{L}$. According to Boyd (1990) if there is notoxic compounds, the minimum dissolved oxygen concentration of $2 \mathrm{mg} / \mathrm{L}$ was sufficient to support normal life aquatic organisms. Salinity in this research ranged between 0.2-35.87 ppt averaging $17,58 \pm 11.2054$ ppt. The salinity of 0-10 ppt live fresh water plankton, the salinity 10-20 ppt live freshwater and marine plankton, whereas at higher salinity of $20 \mathrm{ppt}$ marine plankton life. Above 20 ppt salinity allow phytoplankton to survive, multiply and can actively perform photosynthesis (Sachlan, 1982). Results of $\mathrm{pH}$ measurement in this research ranged from 7.35-9,00 with an average $\mathrm{pH}$ of $8,11 \pm 0.3319$. According to Boyd (1990), that most natural waters have a $\mathrm{pH}$ value of 5-10 with a range of 6.5 to 9.0. Most of the aquatic biota are sensitive to changes in $\mathrm{pH}$ and the like $\mathrm{pH}$ value ranging from 7 to 8.5 .

Table 2. Water quality variables in brackish water pond area of Pasuruan Regency, East Java Province.

\begin{tabular}{lccccc}
\hline Variables & Minimum & Maximum & Average & $\begin{array}{c}\text { Standard } \\
\text { deviation }\end{array}$ & $\begin{array}{c}\text { Optimum } \\
\text { Value }\end{array}$ \\
\hline Temperature $\left({ }^{\circ} \mathrm{C}\right)$ & 27.17 & 34.73 & 31.59 & 1.5099 & $\left.29-31^{*}\right)$ \\
Disssolved Oxygen $(\mathrm{mg} / \mathrm{L})$ & 1.33 & 11.97 & 7.69 & 2.6518 & $\left.4-7^{\star}\right)$ \\
Salinity (ppt) & 0.20 & 35.87 & 17.58 & 11.2054 & $\left.15-25^{\star}\right)$ \\
pH & 7.35 & 9.00 & 8.11 & 0.3319 & $\left.8.0-8.5^{\star}\right)$ \\
TSS $(\mathrm{mg} / \mathrm{L})$ & 1.0 & 167.0 & 39.0 & 33.5202 & $\left.<25^{\star *}\right)$ \\
Nitrite $(\mathrm{mg} / \mathrm{L})$ & 0.0056 & 0.9876 & 0.3235 & 0.3124 & $\left.0-0.25^{*}\right)$ \\
Nitrate (mg/L) & 0.0121 & 1.5953 & 0.3551 & 0.3496 & $\left.0.008^{\star * \star}\right)$ \\
Ammonia (mg/L) & 0.0778 & 2.9707 & 0.9761 & 0.8416 & $\left.0.0 .25^{\star}\right)$ \\
Phosphate (mg/L) & 0.0160 & 0.7285 & 0.1653 & 0.1634 & $\left.0.015^{\star \star *}\right)$ \\
Fe (mg/L) & 0.0008 & 0.0139 & 0.0030 & 0.0028 & $\left.0.01^{\star}\right)$ \\
Total organic matter $(\mathrm{mg} / \mathrm{L})$ & 9.80 & 85.86 & 37.11 & 12.6177 & $\left.29.50^{\star}\right)$ \\
\hline
\end{tabular}

Sources:

$\left.{ }^{*}\right) \quad=$ Poernomo (1992)

$\left.{ }^{* *}\right)=$ Effendi (2003)

$\left.{ }^{* * *}\right)=$ Keputusan Menteri Negara Kependudukan dan Lingkungan Hidup (2004) 
The content of nitrite as an intermediate product of ammonia and nitrate from nitrification process that can be toxic to most aquatic organisms. Nitrite content ranging from 0.0056 to $0.9876 \mathrm{mg} / \mathrm{L}$ with an average of $0.3235 \pm 0.3124 \mathrm{mg} / \mathrm{L}$. Nitrite content optimum water shrimp farms range $0-0.25 \mathrm{mg} / \mathrm{L}$ (Poernomo, 1992). Nitrite content of more than $0.05 \mathrm{mg} / \mathrm{L}$ can be toxic to most aquatic organisms (Moore, 1991).

Nitrate content of the measurement results in this study ranged from $0.0121-1.5953$ $\mathrm{mg} / \mathrm{L}$ withan average value of $0.3551 \pm 0.3496$ $\mathrm{mg} / \mathrm{L}$. These ranges is still within the limits tolerated by the animals akutik. According Mackentum (1969) in Amin (2010) for the growth of phytoplankton require nitrate concentrations from $0.9-3.5 \mathrm{mg} / \mathrm{L}$. Nitrate concentration of more than $0.2 \mathrm{mg} / \mathrm{L}$ may result in eutrophication (enrichment) waters (Effendi, 2003).

The content of ammonia ranged from 0.0778 to $2.9707 \mathrm{mg} / \mathrm{L}$ with an average of $0.9761 \pm 0.8416 \mathrm{mg} / \mathrm{L}$. According to Chamberlain (1988) that the ammonia in the water is converted into nitrite by Nitrosomonas $\mathrm{sp}$ bacterial activity and subsequent nitrite will soon be converted into nitrate by bacteria activity Nitrobacter sp. Optimal conditions for both processes occur when the amount of dissolved oxygen sufficient, good buffer capacity, $\mathrm{pH}$ neutral and low water temperatures. Terms of ammonia total shrimp pond water is $1.0 \mathrm{mg} / \mathrm{L}$ with the optimum of 0.1 $\mathrm{mg} / \mathrm{L}$ (Poernomo, 1992).

Phosphate content ranged from 0.0160 to $0.7285 \mathrm{mg} / \mathrm{L}$ with an average of $0.1653 \pm 0.1634 \mathrm{mg} / \mathrm{L}$. The content of phosphate in natural waters ranged from 0.005 to 0.020 $\mathrm{mg} / \mathrm{L}$, while the ground water is usually about $0.02 \mathrm{mg} / \mathrm{L}$ and rarely exceed $1 \mathrm{mg} / \mathrm{L}$ (Boyd, 1988). According to the KLH (2003), the content of phosphate in the water quality standards that are good for the life of aquatic biota namely $0.015 \mathrm{mg} / \mathrm{L}$. The addition of phosphate fertilizers through fertilization in traditional ponds in Luwu Utara District, Mamuju and Sinjai showed an increase in the amount of plankton (Pirzan et al., 2003).

Fe including the essential elements for the life of aquatic plants including algae and phytoplankton that plays a role as a constituent cytochrome and chlorophyll. Fe can also be a limiting factor for the life of aquatic organisms including plankton, when high levels and under acidic conditions. Fe content ranges from 0.0008 to $0.0139 \mathrm{mg} / \mathrm{L}$ with an average of $0.0030 \pm 0.0028 \mathrm{mg} / \mathrm{L}$. According to Moore (1991), Fe levels $>1.0 \mathrm{mg} / \mathrm{L}$ are considered harmful to the life of aquatic organisms. Fe content requirements for shrimp pond is 0.03 $\mathrm{mg} / \mathrm{L}$ and the optimum of $0.01 \mathrm{mg} / \mathrm{L}$ (Poernomo, 1988).

Total organic matter content ranged from 9.80 to $85.86 \mathrm{mg} / \mathrm{L}$ with an average of $37.11 \pm 12.6177 \mathrm{mg} / \mathrm{L}$. The amount of organic matter content can determine the level of fertility of the waters. Total organic matter content in traditional pond location, obtained above $29.50 \mathrm{mg} / \mathrm{L}$ said quite fertile. According to Poernomo (1992), total organic matter content is good for shrimp farming that is 29.50 $\mathrm{mg} / \mathrm{L}$.

Plankton analysis was obtained the abundance of genus Nitzschia belong to the class Bacillariophyceae (Table 3). According to Nontji (2008) Nitzschia is one component of the class Bacillariophyceae phytoplankton that is cosmopolitan, fast growing in ponds and marine waters as well as natural food preferred by shrimp.

The plankton abundance fluctuation is affected by several factors, including temperature, $\mathrm{pH}$, nutrient concentration, light, weather, disease, predation, competition among species, and algae toxin (Boyd, 1990). In this research, the abundance was in the range of 20.0-6,360.0 individuals/L averaging $401.30 \pm 2,886.43$ individuals/L, where the range was larger compared to that in brackish water pond area in Lamongan Regency, which was in the range of 37.0-1,161.0 individuals/L averaging 386.6 individuals/L (Pirzanet al., 2012), Gresik Regency with range of individuals number of 20-3,798.0 individuals/L averaging 452.4 individuals/L (Pirzan \& Utojo, 2012), North Luwu Regency with range of individuals number of $60-1,110$ individuals/L averaging 252.5 individuals/L (Pirzan \& Mustafa, 2008) as well as East Luwu Regency with range of individuals number of $50-810$ individuals/L averaging 245.0 (Pirzan \& Mustafa, 2010). The difference was because in brackish water pond areas of Gresik, Lamongan, North Luwu and East Luwu Regencies the dominance index was relatively lower (better) compared to that in the research location. This happened because in some locations a genus dominated other genus (the dominance index value was relatively higher). Besides that, because the research location did not have an irrigation (ditch) network, the majority of brackish water ponds only used a creek as a ditch and water changing, following the gravitational manner. Therefore, water changing did not happen smoothly to distribute planktons, so only a certain genus can grow well in this location. 
Table 3. Abundance and number of genera, diversity, uniformity of plankton in brackish water pond area of Pasuruan Regency, East Java Province.

\begin{tabular}{lcccc}
\hline \multicolumn{1}{c}{ Vriables } & Minimum & Maximum & Average & Standard deviation \\
\hline Abundance of plankton (ind./L) & 20.0 & $6,360.0$ & 401.3 & $2,886.43$ \\
Number of genera & 2.0 & 9.0 & 4.0 & 1.8115 \\
Variety index $\left(\mathrm{H}^{\prime}\right)$ & 0.04 & 2.07 & 1.00 & 0.4808 \\
Uniformity index $(\mathrm{E})$ & 0.05 & 1.00 & 0.77 & 0.2763 \\
Dominance index & 0.06 & 0.99 & 0.46 & 0.2427 \\
\hline
\end{tabular}

The number of plankton genera found in this research ranged between 2.0-9.0genera averaging $4.0 \pm 1.8115$ genera (Table 3 ), the range of the number of plankton genera was the same as that in Lamongan Regency, but the average was relatively lower compared to that in brackish water pond area of that regency, i.e. in the range of 2.0-9.0 genera averaging 5.3 genera (Pirzan \& Utojo, 2012). Acid sulfate soil of brackish water pond in North Luwu Regency showed a larger number of genera, i.e. in the range of 2-17 genera (Pirzan \& Mustafa, 2008). This condition occurred because the brackish water pond in this area had an adequate irrigation network. Therefore, it was easy for the brackish water pond farmers to change the pond water so that the water condition was suitable for planktons growth causing the plankton to be well distributed. On the other hand, in the majority of research locations, there was high reliance on the water from a creek, and the majority of irrigation for brackish water pond was with the use of chain system, and water changing was done in a gravitational manner depending on high-low tide difference, causing the water circulation of brackish water pond to be not very smooth that could drastically decrease the water quality and therefore limited the number of genera to grow and develop in locations which were far from water source.

The variety index value in this research ranged between 0.04-2.07 averaging $1.00 \pm 0.4808$ (Table 3) meaning that on average the plankton community in brackish water pond area of Pasuruan Regency was categorized as the minimal requirements for a moderately stable condition. This was in line with Basmi (2000), when $\mathrm{H}^{\prime}<1$, biota community is said to be unstable, when the value of $\mathrm{H}$ ranges $1-3$, the biota community stability is moderate, and when $\mathrm{H}^{\prime}>3$, the biota community stability is in the prime condition. Average variety index value was relatively the same as that in brackish water pond area of Gresik Regency which ranged between 0.06-2.84 averaging 1.1094 (Pirzan \& Utojo, 2012) and Lamongan Regency which ranged between 0.2896-1.8948 averaging 1.0576 (Pirzanet al., 2012). Average variety index was higher compared to that in brackish water pond area in Bone Regency which ranged between 0.101.87 averaging 0.87 (Pirzan \& Utojo, 2010). This difference was because Bone Regency brackishwater pond area had high salinity and water temperature ranging between $37-83 \mathrm{ppt}$ and $31-37{ }^{\circ} \mathrm{C}$, respectively. Average plankton variety on the research location was much higher (better), compared to that in brackish water pond area in Pangkep Regency which ranged between 0.0497-1.2216 averaging 0.8239 (Pirzan \& Utojo, 2011) and Maros Regency which ranged between 0.1550-1.8086 averaging 0.8977 (Pirzan et al., 2011) because environment quality factors decreased.

The uniformity index value in this research ranged between 0.05-1.0 averaging $0.77 \pm 0.2763$ (Table 3 ), on average genera were well distributed and their difference was not significant (Basmi, 2000). The average uniformity index value in this research was relatively higher compared to that in brackish water pond areas in Gresik Regency, with a range of 0.08-1.36 averaging 0.71 (Pirzan \& Utojo, 2012) and Lamongan Regency, ranging between 0.2532-0.9661 and averaging 0.6740 (Pirzanet al., 2012). According to Ali (1994), when the value of $E>0.75$, it is categorized as high or good value of uniformity, whereas when the value of $E<0.75$, the value of uniformity is low. The uniformity index value in this research also showed higher results compared to that in brackish water pond areas of Pangkep and Maros Regencies, which respective uniformity value was in the range of $0.0340-0.8714$ averaging 0.5903 (Pirzan \& Utojo, 2011) and the range of $0.1410-1.1076$ averaging 0.7025 (Pirzan et al., 2011), genera were not well distributed, and finally the water or aquatic area environmental stability could be disturbed at the two locations (Pangkep and Maros Regencies).

The dominance index value in this research ranged between 0.06-0.99 averaging $0.46 \pm 0.2427$ (Table 3 ), meaning that in plankton community structure in this water on average there was no genus dominating other genus. Average dominance index value in this research was relatively the same as that in brackish water pond area in Gresik Regency which ranged between 0.06-0.98 averaging 
0.4085 (Pirzan \& Utojo, 2012) and Lamongan Regency with a range of 0.0435-0.6811 averaging 0.4379 (Pirzanet al., 2012). According to Basmi (2000), dominance index value being close to numeral 1 which means that in the structure of biota community observed there is a genus which extremely dominates other genus. In contrast, dominance index value being close to numeral 0 means that in the structure of biota community observed there is no genus that dominates other genus. Increasing the production of brackish water pond can be done by improving the brackish water ponds lay-out and building an irrigation network because brackish water ponds in the research location does not have an adequate irrigation network. The improvement can also be done by applying early and further fertilizers, using pesticides, adapting seeds to temperature and salinity and drying out the bottom of brackish water pond in an optimum way. The use of fertilizer and pesticide was already revealed during the observation of intensive and traditional brackish water ponds at Lakawali in East Luwu Regency (expansion of North Luwu to become North Luwu and East Luwu) with the ranges of 0.66 and 0.73 , respectively because the use of inorganic fertilizer and antibiotics was not balanced and mangrove forest conversion into brackish water pond was not done correctly (Pirzan et al., 2006). Among other main factors affecting the change of plankton number, variety and dominance were natural habitat destruction, chemical pollution, and climate change (Widodo, 1997).

The relationship strength between water quality variables (Table 2) and plankton abundance simultaneously was obtained from the value of $R$ (correlation coefficient). Based on the calculation result, the $R$ value was found to be 0.228 , meaning that the closeness between water quality variables and plankton abundance was categorized as poor (Priyatno, 2008). The amount of influence of water quality variables towards plankton abundance is shown by the $R^{2}$ value (determination coefficient), which was 0.52 or to $52 \%$. In other words, the amount of plankton abundance that can be explained by water quality variables was $52 \%$ and the rest has to be explained by other causing factors coming from outside of this regression model. Therefore, with the regression model, the plankton abundance could be predicted from the following equation:

\footnotetext{
$\mathrm{Y}=474.264-4.128 \mathrm{X}$

$\mathrm{Y}=$ Plankton abundance (individuals/L)

$X=$ TSS $(\mathrm{mg} / \mathrm{L})$
}

Total suspended solid (TSS) is a solid that neither goes through the holes of filtering paper sized $20 \mu \mathrm{m}$ nor is it solved in water, and it only floats around (APHA, 2005). Total suspended solid in the research location ranged between 1.0-167.0 mg/L averaging $39.0 \pm 33.5202 \mathrm{mg} / \mathrm{L}$ (Table 2), which was lower compared to that in the area of brackish water ponds of milkfish and salt in Jeneponto Regency, i.e. in the range of $4-180 \mathrm{mg} / \mathrm{L}$ (Utojo \& Pirzan, 2009), which was also lower than that in brackish water pond area in Gresik Regency with a range of 15.0-541 mg/L (Pirzan \& Utojo, 2012). Total suspended solid in this research was relatively the same as that in brackish water pond area in Bone Regency with a range of 3-164 mg/L (Pirzan \& Utojo, 2010), but was relatively the same compared to that in brackish water pond area in Lamongan Regency, namely in the range of 12.0-155.0 mg/L averaging $62.47 \mathrm{mg} / \mathrm{L}$ (Pirzanet al., 2012) and negatively affected plankton abundance. Based on the measurement of TSS at Lekok Subdistrict in Pasuruan Regency the value of $51 \mathrm{mg} / \mathrm{L}$ was obtained, while according to water quality limit for fish aquaculture it was $<50 \mathrm{mg} / \mathrm{L}$ (Anonim, 2010b). The maximum range of TSS obtained in this research was amounted to $167.0 \mathrm{mg} / \mathrm{L}$, therefore, with the increase of TSS as much as $1 \mathrm{mg} / \mathrm{L}$, it would decrease plankton abundance as much as 4.128 individuals/L with the provision that other water quality variables did not undergo any changes. According to Effendi (2003), suspended solids positively correlated with turbidity. The higher the value of suspended solids primarily by mud and fine sand fraction in a body of water, turbidity value is also higher. High turbidity can hinder the penetration of light into the water causing phytoplankton photosynthesis process inhibited so as to reduce primary productivity.

\section{Conclusions}

Water quality variables which really affected plankton abundance in traditional brackish water ponds of tiger shrimp ( $P$. monodon) in Pasuruan Regency, East Java was total suspended solid (TSS) as much as 0.52 or $52 \%$.

Plankton abundance was in the range of 20.0-6,360.0 individuals/L averaging $401.3 \pm 2,886.43$ individuals/L. The number of plankton genera ranged between 2.0-9.0 genera averaging $4.0 \pm 1.8115$ genera, the variety ranged between 0.04-2.07 averaging $1.0 \pm 0.4808$, the uniformity ranged between $0.05-1.00$ averaging $0.77 \pm 0.2763$ and the dominance ranged between 0.01-0.99 
averaging $0.46 \pm 0.2427$. Based on biological index values (variety, uniformity, and dominance) on average, this water or aquatic area was categorized as moderately stable, plankton genera were well distributed and there was no genus dominating other genus.

\section{Acknowledgments}

My thanks go to Mr. Hakim for his help in collecting water and plankton samples in the field, also to Miss Sutrisyani, Miss Andi Sahrijanna and Miss Sitti Rohani for their help in analyzing water in laboratory, and also to Miss Irmayani for her help in analyzing plankton.

\section{Refferences}

Ali, I.M. 1994. Struktur komunitas ikan dan aspek biologi ikan-ikan dominan di Danau Sidenreng, Sulawesi Selatan. Thesis Sarjana Fakultas Perikanan. Institut Pertanian Bogor. Bogor. 130 pp.

Amin, M. 2010. Dinamika plankton pada budidaya udang windu (Penaeus monodon Fabr.) yang menggunakan jenis pupuk organik di tambak. Prosiding Forum Inovasi Teknologi Akuakultur 2010. P. 837-844.

Anonim. 2008. Laporan Akuntabilitas Kinerja Instansi Pemerintah (LAKIP-SKPD) tahun 2008. Dinas Kelautan dan Perikanan Kabupaten Pasuruan. Pasuruan. 28 pp.

Anonim. 2010a. Pedoman Perencanaan Pengembangan Kawasan Perikanan Budidaya (Minapolitan). Direktorat Prasarana dan Sarana Budidaya, Direktorat Jenderal Perikanan Budidaya, Kementerian Kelautan dan Perikanan, Jakarta, 48 pp.

Anonim. 2010b. Laporan akhir kajian kualitas tanah tambak di Kabupaten Pasuruan. Balitbang dan Diklat Kabupaten Pasuruan. P. V-20.

Anonym. 2010. Plankton : Why are they important?http://www.st.nmfs.noaa.gov/pl ankton/intro/why.html. Diakses pada tanggal 25 April 2015.

APHA (American Public Health Association). 2005. Standard methods for examination of water and wastewater. Twentieth edition. APHA-AWWA-WEF, Washington, DC., p.10-2-10-18.

Barnes, R.S.K., K. Mann. 1991. Fundamental of Aquatic Ecosystem (Prologue). Blackwell Sci. Publisher Oxford, 226 p.

Basmi, H.J. 2000. Planktonologi. Plankton sebagai indikator kualitas perairan. Fakultas Perikanan dan IImu Kelautan. Institut Pertanian Bogor. 60 p.

Botes, L. 2003. Phytoplankton identification catalogue. Globallas Monograph Series No. 7. Programme Condition Unit Global Ballast Water Management Programme International Marine Organization. London. 77 pp.

Boyd, C.E. 1988. Water Quality in Warmwater Fish Ponds. Fourth printing. Alabama Agricultural Experiment Station, Auburn University, Alabama. 359 pp.

Boyd, C.F. 1990. Water quality in ponds for aquaculture. Auburn University, Alabama USA. 482 pp.

Chamberlain, W.G. 1988. Tinjauan kembali pengelolaan tambak udang, dalam Prinsip Pengelolaan Budidaya Udang.Technical Bulletin. P. 48-64.

Effendi, H. 2003. Telaah Kualitas Air Bagi Pengelolaan Sumberdaya dan Lingkungan Perairan. Penerbit Kanisius (Anggota IKAPI), Yogyakarta. 258 pp.

Haryadi, S., Suryodiptro, I.N.N., Widigdo, B. 1992. Limnologi. Penuntun praktikum dan metode analisa air. Fakultas Perikanan. Institut Pertanian Bogor. Bogor. 57 pp.

KLH. 2003. Keputusan Menteri Negara Kependudukan dan Lingkungan Hidup, No. 51 tahun 2004, tanggal 8 April 2004 tentang Baku Mutu Air Laut. Kementerian Lingkungan Hidup, Jakarta. $11 \mathrm{pp}$.

Moore, J.W. 1991. Inorganic Contaminants of Surface Water. Springer-Verlag. New York. 334 pp.

Pirzan, A.M., Gunarto., Utojo. 2003. Plankto diversity and relationship with phosphate in brackishwater pond of South Sulawesi. International Seminar on Marine and Fisheries. Agency for Marine and 
Fisheries Research. Ministry of Marine Affairs and Fisheries. Jakarta. P. 51-57.

Pirzan.A.M., Pong Masak, P.R. 2007. Hubungan produktivitas tambak dengan keragaman fitoplankton di Sulawesi Selatan. Jurnal Riset Akuakultur. 2(2):211-220.

Pirzan, A.M., Mustafa, A. 2008. Peubah kualitas air yang berpengaruh terhadap plankton di tambak tanah sulfat masam Kabupaten Luwu Utara, Sulawesi Selatan. Jurnal Riset Akuakultur 3 (3):263-374.

Pirzan, A.M., Mustafa, A. 2010. Peubah kualitas air yang berpengaruh terhadap kelimpahan plankton di tambak tanah sulfat masam Kabupaten Luwu Timur, Sulawesi Selatan. Dalam Jumanto, Saksono, H., Probusunu, N., Widaningroem, R., Suadi dan Istiqomah, I (eds). Prosiding Seminar Nasional Tahunan VII Hasil Penelitian Perikanan dan Kelautan Tahun 2010. Jilid II. Manajemen Sumberdaya Perikanan. Jurusan Perikanan dan Kelautan Fakultas Pertanian Universitas Gadjah Mada. Yogyakarta. P. 1-9.

Pirzan, A.M., Utojo. 2010. Keragaman plankton dan kondisi lingkungan perairan kawasan tambak Kabupaten Bone, Provinsi Sulawesi Selatan. Dalam Syamsuddin, S., Yulianti, H.S., Saifurridjal, Basith, A., Nurbani, S.Z., Suharto, Siregar, A.N., Rahardjo, S., Hadi, R.S. dan Sanova, B.V. (eds). Prosiding Seminar Nasional Perikanan 2010. Melindungi Nelayan dan Sumber Daya Ikan. Sekolah Tinggi Perikanan. Jakarta. P. 8-15.

Pirzan, A.M., Utojo., Mustafa, A. 2011. Hubungan kualitas air yang berpengaruh terhadap keragaman plankton di Kawasan pertambakan Kabupaten Maros, Provinsi Sulawesi Selatan. Dalam Sudrajat, A., Azwar, Z.I., Supriyadi, H., Rachmansyah, Sumiarsa, G.S., Kristanto, A.H., Imron, Parenrengi, A., Insan, I., Kusrini, E. (eds). Forum Inovasi Teknologi Akuakultur. Pusat Penelitian dan Pengembangan Perikanan Budidaya. Badan Litbang Kelautan dan Perikanan. Jakarta. P. 905-914.

Pirzan, A.M., Utojo. 2011. Hubungan antara kelimpahan plankton dan peubah kualitas air di Kawasan tambak Kabupaten
Pangkep Provinsi Sulawesi Selatan. Dalam Sudrajat, A., Azwar, Z.I., Supriyadi, H., Rachmansyah, Sumiarsa, G.S., Kristanto, A.H., Imron, Parenrengi, A., Insan, I. dan Kusrini, E. (eds). Forum Inovasi Teknologi Akuakultur. Pusat Penelitian dan Pengembangan Perikanan Budidaya. Badan Litbang Kelautan dan Perikanan. Jakarta. P. 915-924.

Pirzan, A.M., Utojo. 2012. Hubungan antara kelimpahan plankton dan peubah kualitas air di tambak Kabupaten Gresik, Provinsi JawaTimur. Dalam Taufiqurrohman, M., Prayogi, U. dan Winarno, A. (eds). Prosiding Seminar Kelautan VIII. Pengelolaan Sumber Daya Berbasis IPTEK untuk Kemakmuran Bangsa. Universitas Hang Tuah Surabaya. P. B3106-B3 115.

Pirzan, A.M., Utojo., Hendrajat, E.A. 2012. Hubungan antara jumlah individu plankton dan variabel kualitas air di kawasan pertambakan Kabupaten Lamongan, Provinsi Jawa Timur. Dalam Taufiqurrohman, M., Prayogi, U. dan Winarno, A. (eds). Prosiding Seminar Kelautan VIII. Pengelolaan Sumber Daya Berbasis IPTEK untuk Kemakmuran Bangsa. Universitas Hang Tuah Surabaya. P. B343-B3 53.

Poernomo, A. 1988. Pembuatan Tambak Udang di Indonesia. Seri Pengembangan No. 7. Balai Penelitian Perikanan Budidaya Pantai, Maros. 40 pp.

Poernomo, A. 1992. Pemilihan Lokasi Tambak Udang Berwawasan Lingkungan. Pusat Penelitian dan Pengembangan Perikanan. Jakarta. $40 \mathrm{pp}$.

Priyatno, D. 2008. Mandiri Belajar SPSS (Statistical Product and Service Solution) untuk Analisis Data dan Uji Statistik. Media Kom. 143 pp.

Sachlan, M. 1982. Planktonologi. Direktorat Jenderal Perikanan. Jakarta. 140 pp.

SPSS (Statistical Product and Service Solutions). 2006. SPSS 15.0 Brief Guide. SPSS Inc., Chicago. 217 pp.

Utojo., Pirzan, A.M. 2009. Kondisi plankton di tambak bandeng dan garam Kabupaten Jeneponto, Sulawesi Selatan. Dalam Jumanto, Dwiyitno, Chasanah, Heruwati, 
E.S., Irianto, H.E., Saksono, H. , Iwan Yusuf, B.L., Basmal, J., Murniati, Murwantoko, Probusunu, N., Rosmawaty, P., Rustadi dan Ustadi (eds). Prosiding Seminar Nasional Tahunan VI Hasil Penelitian Perikanan dan Kelautan Tahun 2009. Jurusan Perikanan dan Kelautan Fakultas Pertanian Universitas Gadjah Mada. Yogyakarta. P. 1-8.

Widodo, J. 1997. Biodiversitas sumberdaya perikanan laut peranannya dalam pengelolaan terpadu wilayah pantai. Dalam Mallawa, A., R. Syam, N. Naamin, S. Nurhakim, E.S. Kartamihardja, A. Poernomo dan Rachmansyah (eds). Prosiding Simposium Perikanan Indonesia II. Ujung Pandang 2-3 Desember 1997. P. 136-141.

Yamaji, J. 1976. Ilustration of Marine Plankton. Hoikusk Publishing. Co Ltd. Japan. 369 pp. 